\title{
Yeni Bilirkişilik Mevzuatı Çerçevesinde Muhasebe Meslek Mensuplarına Verilen Bilirkişilik Temel Eğitimleri Üzerine Bir Değerlendirme
}

(Araştırma Makalesi)

An Evaluation about Expertise Educations of Certificated Public Accountants within the Frame of New Expertise Legislation

Doi: 10.29023/alanyaakademik.604843

\section{Mehmet UTKU}

Dr. Öğr. Üyesi, Pamukkale Üniversitesi, İktisadi ve İdari Bilimler Fakültesi, Işletme Bölümü mutku@pau.edu.tr

Orcid ID: https://orcid.org/0000-0002-7076-6891

\section{Emin KURTCEBE}

Dr., Denizli Serbest Muhasebeci Mali Müşavirler Odası, Genel İdare Müdürü

eminkurtcebe@gmail.com

Orcid ID: https://orcid.org/0000-0002-8147-0332

Bu makaleye atıfta bulunmak için: Utku, M., Kurtcebe, E. (2019). Yeni Bilirkişilik Mevzuatı Çerçevesinde Muhasebe Meslek Mensuplarına Verilen Bilirkişilik Temel Eğitimleri Üzerine Bir Değerlendirme. Alanya Akademik Bakıs, 3(3), Sayfa No. 261-276.

\section{Anahtar kelimeler: \\ Bilirkişilik, Yeni Bilirkişilik Kanunu, Bilirkişilik Temel Ĕgitimleri, Mali Müşavir}

Makale Geliş Tarihi: 09.08.2019

Kabul Tarihi:

18.09.2019

\section{ÖZET}

6754 sayılı yeni Bilirkişilik Kanunu'nun getirdiği en önemli yeniliklerden birisi bilirkişilik temel eğitimidir. Bu çalışmada amaçlanan, muhasebe meslek mensuplarının, bilirkişilik temel eğitimi hakkındaki görüşlerini analiz etmek ve eğitimlerin gelişimine katkı sunabilmektir. Çalışmada, Denizli SMMM Odası'nda gerçekleştirilen bilirkişilik temel eğitimlerine katılan muhasebe meslek mensuplartyla anket yaplarak toplanan veriler, SPSS programıyla analiz edilmiştir. Katılımcıların eğitim hakkındaki görüşlerinin, alt gruplar açısından farklılık gösterip göstermediği t-testi ve varyans analizi yardımıyla araştırılmıştır. Araştırma sonuçlarına göre, bilirkişilik temel eğitimine ilişkin memnuniyet düzeyi oldukça yüksek olmakla birlikte, eğitimin süresi ve bilgi ihtiyacını karşılama düzeyi gibi konularda memnuniyet düşmüş̧ı̈r. Meslekte deneyimli olan katılımclların diğerlerine göre daha fazla memnun kaldıkları söylenebilir. 
Keywords:

Expertising, New Expertise Legislation, Basic Education of Expertising, Certified Public Accountants

\begin{abstract}
One of the most important innovations brought by the new Law of Expertise No. 6754 is basic education of expertise. The aim of this study is to analyze the opinions of professional accountants about basic education of experts and to contribute to the development of education. The survey data collected from the accountants who participated in the basic education of expertise in Denizli Chamber of Certified Public Accountants (DSMMMO), were analyzed with SPSS program. T-test and variance analysis were used to determine whether participants' views on education differed in terms of subgroups. According to the results of the study, although the satisfaction level for the basic education of the expertise is quite high, satisfaction levels such as the duration of the education and the level of meeting the information needs decreased. It can be said that the participants who are experienced in the profession are more satisfied than others.
\end{abstract}

\section{GİRIŞ}

Tüm dünyada, hukukun uygulanmasında, hukuk kuralları çerçevesinde mevcut delillere dayanarak destek veren en önemli unsurlardan birisi bilirkişilik müessesidir. Türk yarg1 sistemi, cumhuriyetin kuruluşundan itibaren bu müessese ile birlikte hareket etmek suretiyle adaletin tecelli edilmesini sağlamaktadır (Güneş, 2015: 7). Türkiye koşullarında mahkemelerin ağır iş yükü ve uzmanlık bilgisi gerektiren davalar sebebiyle bilirkişilik müessesesi büyük önem arz etmektedir.

Bilgisiyle ve deneyimiyle yargılamaya katılan bilirkişinin en önemli ve birinci özelliği her şeyden önce konusunun uzmanı olması, bunu tarafların ve toplumun kabul etmesidir (İnan vd., 2010: 4). Hızlı değişim ve gelişimlerin yaşandığı çağımızda, uzmanlığa duyulan gereksinim durmadan artmaktadır. Buna mahkemelerin iş yükünde süregelen artışı da eklersek yargılama işlerinde, arabulucuların, uzlaştırmacıların ve bilirkişilerin fonksiyonlarının daha da artacağı bir gerçektir.

Bilirkişiliğe duyulan gereksinimin artması, profesyonelleşmeyi de beraberinde getirmiştir. Bilirkişilik profesyonelce yapıldığında, gerek yargılama usulünün bilinmesi, gerekse mahkemenin ihtiyacı olan teknik bilgilerin sağlanmasıyla adalete daha iyi bir hizmet verilebilecektir. Bu doğrultuda, 24.11.2016 tarihinde 6754 sayılı Bilirkişilik Kanunu ve 03.08.2017 tarihinde de Bilirkişilik Yönetmeliği yayınlanarak yürürlüğe girmiştir. Bu kanun ve yönetmelik çerçevesinde; bilirkişiliğe kabul şartları arasına 24 saatlik Bilirkişilik Temel Eğitimi konulmuştur. Bilirkişilik Kanunu ile getirilen yeniliklerden biri olan bilirkişilik temel eğitimi, bilirkişi adaylarının mesleklerine ve uzmanlık alanlarına yönelik bir eğitim olmayıp bilirkişilik görevinin ifası sırasında ihtiyaç duyacakları temel bilgilerin verildiği bir eğitimdir (Erdoğan vd., 2017). Bilirkişilik müessesesinin hukuk sistemi içerisindeki önemi göz önüne alındığında, etkin ve verimli bir kurumsal yapı oluşturma noktasında temel eğitim, nitelikli bilirkişiler yetiştirmenin önemli bir adımıdır.

İlgili mevzuat çerçevesinde; Adalet Bakanlığı'nca eğitim yetkisi alan Türkiye Serbest Muhasebeci Mali Müşavirler ve Yeminli Mali Müşavirler Odaları Birliği (TÜRMOB), 2017 yılı sonu itibariyle, bağlı odalar vasıtasıyla eğitimlerini gerçekleştirmeye başlamıştır. 
Bu makale çalışmasında; bilirkişilik kavramı ve yasal çerçeve, mali müşavirlik mesleğinde bilirkişilik, bilirkişilik temel eğitimi ve Denizli SMMM Odası'nda meslek mensuplarına yönelik gerçekleştirilen bilirkişilik temel eğitimlerinin analizi yer almaktadır.

\section{KURAMSAL ÇERÇEVE}

\subsection{Bilirkişilik Kavramı ve Yasal Çerçeve}

Birçok tanımı olmakla birlikte genel anlamda bilirkişilik, hukuk kurallarıyla çözülemeyecek ölçüde teknik ve mesleki bilgi ihtiva eden bir takım anlaşmazlıkların çözümünde, mahkemelerin alanında uzman kişiler tarafından yapılan incelemelere dayanarak karar vermelerini sağlayan müessesedir.

Bilirkişi, 6754 sayılı kanun çerçevesinde "Çözümü, uzmanlığı, özel veya teknik bilgiyi gerektiren hallerde oy ve görüşünü sözlü veya yazılı olarak vermesi için başvurulan gerçek veya özel hukuk tüzel kişisini” ifade eder.

Çağdaş hukuk sistemlerinde sıklıkla başvurulan ve önemli bir ispat aracı olan bilirkişilik müessesesinin, adalet sisteminin sağlıklı işleyebilmesi ve yargılama faaliyetlerinin hızlı ve sorunsuz ilerlemesi için sağlam temellere dayandırılması gerekir. Bu doğrultuda, geçmişte yaşanan sorunlar da dikkate alınarak, 6754 sayılı Bilirkişilik Kanunu 24.11.2016 tarihinde 29898 sayılı Resmi Gazete 'de yayımlanarak yürürlüğe girmiştir. Kanunla, etkin ve verimli bir kurumsal yapı oluşturulmak amaçlanmıştır.

6754 sayılı Bilirkişilik Kanunu'nu takiben 03.08.2017 tarihinde Bilirkişilik Yönetmeliği yayımlanmıştır. Bilirkişi mevzuatı çerçevesinde bilirkişiler; bağımsız, dürüst, tarafsız (objektif), güvenilir ve alanında yetkin kişiler olmalıdır.

Bilirkişilik kanununda ortaya konan temel ilkeler (md.3) doğrultusunda bilirkişi, görevini dürüstlük çerçevesinde bağımsız ve objektif olarak yürütür. Raporunda kişisel bilgisi ve uzmanlığını gerektiren durumlar dışında açıklama yapamaz. Ayrıca bilirkişi, aldığı görevi bizzat yerine getirmekle yükümlüdür. Kısmen de olsa başka bir kimseye devredemez. Görevi sona erse bile bilirkişiliği nedeniyle edindiği bilgi ve sırların gizliliğinin korunması ile yükümlüdür.

Bilirkişi bağımsız olmak zorundadır ve bir konu hakkındaki görüşünü beyan ederken herhangi bir kurum veya makamın etkisi altında kalmadan görüşünü özgürce ifade etmelidir. $\mathrm{Bu}$ doğrultuda bağımsızlığına zarar verecek tutum ve davranışlardan uzak durmalıdır. Ayrıca bilirkişi, görevlendirildiği konularda, din, dil, ırk, cinsiyet, siyasi düşünce vb. sebeplerle ayrım yapmaksızın dürüst ve tarafsız olmalıdır. Uyuşmazlığın taraflarına eşit mesafede olması beklenen bilirkişi, saygınlığını ve adalete olan güveni zedeleyecek her türlü davranıştan kaçınır ve kendine verilen görevi her türlü menfaatin üzerinde tutarak layıkıyla yerine getirir.

Son olarak bilirkişiler, alanında uzman kişiler olmalı ve görev icra noktasında gerekli mesleki özeni göstermelidir. Yargılamada bilirkişiye olan ihtiyaç göz önüne alındığında, bilirkişilerin özel veya teknik bilgi açısından ilgili alanda gerçekten uzman olması ve bu uzmanlığını paylaşması beklenir. Uzmanlığın öneminin yanında, bu uzmanlığın taraflarca kolaylıkla anlaşılabilecek bir dil ile raporlara yansıtılması gerekliliği kaçınılmazdır.

6754 sayılı Bilirkişilik Kanunu'nun 10. maddesinde, bilirkişilik faaliyetinde bulunacak gerçek kişilerde aranan şartlar şu şekilde sıralanmıştır:

a) 26.09.2004 tarihli ve 5237 sayılı Türk Ceza Kanununun 53. maddesinde belirtilen süreler geçmiş olsa bile; kasten işlenen bir suçtan dolayı bir yıldan fazla süreyle hapis cezasına ya da affa uğramış olsa bile Devletin güvenliğine karşı suçlar, Anayasal düzene 
ve bu düzenin işleyişine karşı suçlar, zimmet, irtikâp, rüşvet, hırsızlık, dolandırıcılık, sahtecilik, güveni kötüye kullanma, hileli iflas, ihaleye fesat karıştırma, edimin ifasına fesat karıştırma, suçtan kaynaklanan malvarlığı değerlerini aklama veya kaçakçılık, gerçeğe aykırı bilirkişilik veya tercümanlık yapma, yalan tanıklık ve yalan yere yemin suçlarından mahkûm olmamak.

b) Terör örgütleriyle iltisaklı veya irtibatlı olmamak.

c) Daha önce kendi isteği dışında bilirkişilik sicilinden çıkarılmamış olmak.

ç) Disiplin yönünden meslekten veya memuriyetten çıkarılmamış ya da sanat icrasından veya mesleki faaliyetten geçici ya da sürekli olarak yasaklanmamış olmak.

d) Başka bir bölge kurulunun listesine kayıtlı olmamak.

e) Bilirkişilik temel eğitimini tamamlamak.

f) Bilirkişilik yapacağı uzmanlık alanında en az beş yıl fiilen çalışmış olmak ya da daha fazla çalışma süresi belirlenmiş ise bu süre kadar fiilen çalışmış olmak.

g) Meslek mensubu olarak görev yapabilmek için mevzuat tarafindan aranan şartları haiz olmak ve mesleğini yapabilmek için gerekli olan uzmanlık alanını gösteren diploma, mesleki yeterlilik belgesi, uzmanlık belgesi veya benzeri belgeye sahip olmak.

g) Bilirkişilik temel ve alt uzmanlık alanlarına göre belirlenen yeterlilik koşullarını taşımak.

Yukarıdaki şartları sağlayan gerçek kişiler, yerleşim yerinin veya mesleki faaliyetlerini yürüttüğü yerin bağlı olduğu "Bölge Kuruluna" ya da "Adli veya İdari Yarg1 İlk Derece Mahkemesi Adalet Komisyonuna”, "Bilirkişilik Yönetmeliği” md.40'da belirtilen belgeleri ibraz ederek başvuruda bulunur.

Başvuruları değerlendiren bölge kurulu, gerekli koşulları taşıyanları sicile ve listeye kaydedilmesine karar verir. Bilirkişiliğe kabul edilen kişilere üç yıl geçerliliği olan bilirkişilik yetki belgesi verilir ve bilirkişilik siciline kaydedilir. Bilirkişilik siciline kaydedilenler, yemin ettirilmek suretiyle bilirkişilik listesine alınır ve resen veya talep üzerine ilgili merci tarafindan görevlendirilir.

Görevlendirilen bilirkişiye, inceleyeceği konunun kapsamı yazılı olarak ayrıntısıyla bildirilir. İncelemeye konu belgeler imza karşılığında teslim edilir. Bundan sonra bilirkişi verilen süre içerisinde raporunu hazırlayıp sunmakla yükümlüdür. Belirlenen sürelerde yükümlülügünü yerine getirmeyen bilirkişilerin yerine bir başkası görevlendirilebilir. Bilirkişi raporu, görevlendirme merci tarafından değerlendirilir. Bilirkişiden raporda ortaya çıkabilecek belirsizliklerin giderilmesini sağlamak için yeni sorular yöneltilmek suretiyle ek rapor da istenebilir.

Bilirkişiler, yürüttükleri faaliyetlerin mevzuata uygunluğu açısından Bölge Kurullarınca denetlenirler. Bölge Kurulları bilirkişilerin hazırlayacağı raporları teknik bilgi yönüyle değil sadece ilgili kanun ve yönetmeliklerdeki usul ve esaslar açısından denetleyebilirler. 


\subsection{Bilirkişilik Temel Eğitimi}

Bilirkişilik alanındaki reform ihtiyacına çözüm getirecek ve bilirkişilik kurumunu bütün boyutlarıyla ele alarak bilirkişilerin kalite standardının tesisi ve etkin bir denetim mekanizmasının kurulmasını amaçlayan Bilirkişilik Kanunu ile birlikte Türkiye ilk defa bu alanda müstakil bir Kanuna sahip olmuştur (Erdoğan vd., 2017).

Bilirkişilik kanunuyla getirilen önemli değişikliklerden birisi de eğitim konusudur. İlgili yönetmelik ve genelgelerde uygulama usul ve esasları ayrıntısıyla belirlenen temel eğitim, bilirkişi listesine kaydolmanın ön koşullarından birisidir.

Bilirkişilik yönetmeliğinde yer alan bilirkişilik temel eğitimi, beş yıllık meslekî kıdem kazanmış kişiler tarafından alınan ve bilirkişilik faaliyetinin yürütülmesi ile ilgili temel, teorik ve pratik bilgileri içeren eğitimi ifade eder.

Bilirkişilik müessesesinin hukuk sistemi içerisindeki önemi göz önüne alındığında, geçmişten beri giderek artan bilirkişi kaynaklı birtakım sorunların çözümü ve etkin ve verimli bir kurumsal yapı oluşturma noktasında temel eğitim nitelikli bilirkişiler yetiştirmenin önemli bir adımidir.

Bilirkişilik temel eğitiminin usul ve esasları Bilirkişilik Yönetmeliği'nin dördüncü bölümü ve Bilirkişilik Daire Başkanlığı'nın 11.08.2017 tarih ve 169 nolu genelgesinde ortaya konmaktadır:

- Temel eğitim, on sekiz saati teorik ve altı saati uygulamalı olmak üzere en az yirmi dört ders saatinden oluşur ve yüz yüze eğitim yöntemi uygulanır. Bir günde altı ders saatinden fazla eğitim verilemez.

- Temel eğitim programı, bir sınıfta en fazla 24 katılımcı ile yürütülür.

- Teorik eğitim; yargılama hukukunun genel ilkeleri, bilirkişilik mevzuat hükümleri, bilirkişinin taşıması gereken nitelikler, bilirkişinin yetkileri ve yükümlülükleri, uyması gereken temel ve etik ilkeler, ispat faaliyeti ve bilirkişi incelemesinin usul ve esasları, teknik konu - hukuki konu ayrımına ilişkin usul ve esaslar ile rapor yazım usul ve tekniğini kapsar.

- Uygulama eğitimi; UYAP (Ulusal Yargı Ağı Bilişim Sistemi) Bilirkişi Bilgi Sisteminin kullanılması, katılımcıların bireysel veya heyet hâlinde sistematik teknikleri kullanma becerilerini geliştirmelerini sağlayacak örnek bir olaya ilişkin bilirkişi raporu düzenleme ile uygulama gözetimi faaliyetlerini içerir.

- Temel eğitime katılım zorunlu olup eğitim kuruluşlarınca, katılımcıların derslere devam durumunu gösterir çizelge düzenlenir ve derslerin 1/12'sine devam etmeyenlerin eğitim programıyla ilişiği kesilir.

- Bilirkişilere, bilirkişilik eğitim izni verilen kuruluşlarca teorik ve uygulamalı, toplam altı saatten az olmamak üzere üç yılda bir defa yenileme eğitimi verilir. Bilirkişiler yenileme eğitimine sicile kaydedildiği tarihten itibaren üçüncü yılın içinde katılmak zorundadır.

İlgili yönetmelik ve genelge kapsamında ayrıca bilirkişilik temel eğitimini verecek eğitim kuruluşları hakkında da ayrıntılı bilgilendirme yapılmıştır. Buna göre temel eğitim: Bilirkişilik Daire Başkanlığı'nca izin verilen; Üniversiteler, TÜRMOB ve bağlı odalar, 
Türkiye Barolar Birliği ve Barolar, TMMOB ve bağlı odalar, Adli Tıp Kurumu, Türk Tabipleri Birliği ve bağlı odalar vb. kuruluşlarca verilebilir. Eğitimi verecek kurum, Bilirkişilik Daire Başkanlığı'ndan izin alabilmek için, planlanan eğitim programı, eğiticilerin yeterlilikleri ve eğitimin yapılacağı yer ile ilgili ayrıntılı bilgi verir. İstenen koşulları sağlayan kuruluşlar, 3 yıl için geçerli olmak üzere eğitim verme izni alırlar ve bu kuruluşlar tarafından verilecek eğitimler, içerik, eğitici yeterliliğii, fiziksel mekânlar açısından denetlenirler. Eğiticiler noktasında ise; teorik eğitimi, hukuk alanında en az doktora düzeyinde unvanı olan kişiler, uygulama eğitimini ise en az 5 yıl bilirkişilik deneyimi olan kişiler verebilmektedir.

\subsection{Mali Müşavirlik Mesleği ve Bilirkişilik}

Çözümü yargıya intikal eden anlaşmazlıklarda, mahkemelerin uzmanlığına başvurduğu kişilerin başında Mali Müşavirler gelmektedir. Bunun temel nedeni, hangi alanda olursa olsun mahkemeye konu olan olayların birçoğunun ekonomik ya da finansal bir tarafının olmasıdır.

3568 sayılı "Serbest Muhasebeci Mali Müşavirlik ve Yeminli Mali Müşavirlik Kanunu" Madde 2'de açıkça belirtildiği üzere; muhasebe meslek mensupları, işletmecilik, muhasebe, finans ve mali mevzuat konularında bilirkişilik yapma hakkına sahiptir. Bu çerçevede bilirkişilik mali müşavirlik mesleğinin konularından birini oluşturur.

Muhasebe mesleğinin uygulaması özel ve teknik bilgiyi gerektirdiğinden meslek mensupları bilirkişilik faaliyetlerinin yürütülmesiyle adalet sisteminin işleyişine önemli katkılar sunmaktadırlar. Bu doğrultuda meslek mensupları sahip oldukları bilgi birikimi ve mesleki tecrübeleriyle görevlendirildikleri dosyalar üzerinde muhasebenin temel kavramları ve finansal tablo düzenleme ilkelerinden hareketle gerekli incelemeleri yaparak, mahkemelerin alacakları kararlarda onlara yol gösterici olan raporları hazırlarlar. Muhasebe meslek mensuplarının bilirkişi olarak görevlendirildikleri durumlar dikkate alındığında, muhasebe alanında sahip olunması gereken yetkinliğin yanında, meslek mensuplarının özellikle, vergi hukuku, ticaret hukuku, borçlar hukuku, iş hukuku, ceza hukuku gibi hukuk dallarında da yeterli bilgi birikimine sahip olması gerekir.

Ticari hayattaki birtakım anlaşmazlıkların çözümünde meslek mensuplarından genellikle; borç ve alacakların tespiti, şirket ortaklık yapılarının ve özsermayelerinin tespiti, tasfiye şartlarının tespiti, işletme varlıklarının tespiti gibi konularda bilirkişi olarak rapor istenmektedir. $\mathrm{Bu}$ çerçevede mahkemenin bilirkişi atama kararında belirlediği görevleri yerine getirmekle yükümlü olan meslek mensuplarından, işletmelerin defter, belge ve kayıtlarını incelenmesi de istenmektedir. Bilirkişiler tarafından anlaşmazlığa konu olan yıllar itibariyle, işletmelerin defter ve belgeleri incelenmekte, muhasebe kayıtlarının ve defter tasdiklerinin usulüne uygun olarak yapılıp yapılmadığg, defterlerin delil niteliği taşıyıp taşımadıkları belirlenmektedir.

Ticari uyuşmazlıkların yanında, konunun başında da belirtildiği gibi birçok anlaşmazlığın ekonomik bir tarafı vardır. Örneğin, basit bir boşanma davasında ödenecek nafakanın tespitinde mahkeme, taraflardan birinin ortağı olduğu işletmenin mali tablolarının incelenmesini isteyebilir. Dolayısıyla muhasebe meslek mensuplarının bilirkişiliği adalet sisteminin işleyişi içerisinde önemli bir yere sahiptir. 


\section{LITERATÜR}

6754 sayılı yeni bilirkişilik kanunuyla birlikte, bilirkişilik alanında uygulanmaya başlayan "Bilirkişilik Temel Eğitimleri” özelinde literatürde herhangi bir çalışma bulunmamaktadır. Bu bölümde yeni bilirkişilik mevzuatıyla ilgili çalışmalara yer verilmiştir.

Recep Akcan (2015), yeni bilirkişilik kanunu tasarı aşamasındayken, taslak hakkındaki tespitlerini ortaya koyduğu çalışmasında, taslak hakkında genel bilgiler vermiş ve taslağın sistematik yapısını açıklamaya çalışmıştır. Ayrıca yeni kanunun, henüz taslak aşamasındayken nasıl hazırlanması gerektiği hususunda önerilere yer vermiştir. Özellikle yabancı hukuki düzenlemelerin incelenmesi gerektiğini belirtmiştir.

Başar Soydan ve Özgür Biyan (2016), 6754 sayılı bilirkişilik kanununu inceleme konusu yapmışlar ve bu kanunla bilirkişilik müessesesinin kurumsallaştı̆̆ı sonucuna varmışlardır. Çalışmada kurumsallaşmanın etkinliği ve yeterliliği çeşitli açılardan irdelenip, çözüm önerileri ortaya konulmuştur. Ayrıca disiplin ve ceza hükümleri, bilirkişilik ücretleri, bilirkişilik kurullarının teşkili ve organizasyonu gibi konularda kanunun yetersiz olduğu ya da eksik kaldığı hususlar ayrıntısıyla aktarılmıştır.

Murat Atalı (2016), çalışmasında yeni bir bilirkişilik kanunu hazırlanmasının yasal gerekçesi üzerinde durmuş, bu gerekçe üzerinden bilirkişiliğin kurumsal yapılanması ve hukuki konularda yeni kanuna birtakım eleştirilerde bulunmuştur.

İmdat Türkay (2017), çalışmasında 6754 sayılı bilirkişilik kanununun genel değerlendirmesini yapmış, yasal düzenlemenin gerekçelerini, bilirkişilik müessesesine yöneltilen eleştirileri ve bu bağlamda yeni kanunun amaç kapsam ve temel ilkelerini ortaya koymuştur. Çalışmasında ayrıca değiştirilen ve yürürlükten kaldırılan hükümlere de yer vermiştir.

Ahmet Nezih Kök (2017), 6754 sayılı bilirkişilik kanunu ile gündeme gelen yenilikleri ele alarak ilgilileri bilgilendirmeyi amaçlayan çalışmasında, özellikle bilirkişilik müessesesinde kurumsallaşma adına getirilen yenilikleri ayrıntısıyla aktarmıştır. Ayrıca bilirkişilik temel eğitimlerinin, yapılan faaliyetin kalitesini artırırken standardizasyon sağlayacağı sonucuna varmıştır.

Harun Kısacık (2018), çalışmasında 6754 sayılı bilirkişilik kanunu bağlamında adli muhasebenin bir alt kolu olan muhasebe bilirkişiliği mesleğini tanıtmıştır. Yeni düzenlemelerle birlikte bilirkişiliğin, hukuki davaların çözümünde daha etkin rol oynayacağ1 sonucuna ulaşı1lmıştır

\section{ARASTIRMA TASARIMI ve METODOLOJISİ}

\subsection{Araştırmanın Amacı ve Yöntemi}

6754 sayılı Bilirkişilik Kanunu’nun getirdiği en önemli yeniliklerden birisi önceki bölümlerde de ayrıntısıyla belirtildiği gibi, bilirkişilik temel eğitimidir. Bilirkişilik faaliyetinde bulunacak gerçek kişiler bu temel eğitimi tamamlamak zorundadırlar. Muhasebe meslek mensupları da bilirkişilik faaliyetlerinin yürütülmesi noktasında mahkemelerin uzmanlığına başvurduğu meslek gruplarının başında gelmekte ve sistemin işleyişinde önemli rol oynamaktadırlar.

$\mathrm{Bu}$ çalışmada amaçlanan, ortaya çıkan bu yeni durumda, Denizli ilinde faaliyet gösteren muhasebe meslek mensuplarının, aldıkları bilirkişilik temel eğitimi hakkındaki görüşlerinin 
tespit edilmesidir. Bu doğrultuda eğitime katılanların, gerek eğitimin süresi, gerekse eğiticiler ve eğitimin içeriği açısından memnuniyet düzeyleri ortaya konmaya çalışılmıştır.

$\mathrm{Bu}$ çalışmada veriler, anket yöntemi kullanılarak toplanmıştır. Anket, Denizli Serbest Muhasebeci Mali Müşavirler Odası eğitim salonunda, eğitimin sonunda elden bırakıp alma yöntemiyle uygulanmıştır. Bu sayede tüm katılımcıların görüşlerine ulaşılmıştır. Anket, üç temel bölümden oluşmaktadır. İlk bölümde katılımcılardan eğitimin zamanlaması, süresi ve mekan ile ilgili; ikinci bölümde eğiticilerin ve eğitimin içeriği ile ilgili değerlendirmelerini belirtmeleri istenmiştir. Üçüncü ve son bölümde ise eğitimle ilgili genel memnuniyet seviyesi tespit edilmeye çalışılmıştır. Bu çerçevede muhasebe meslek mensuplarına 5'li likert ölçeğine göre hazırlanmış sorular yöneltilmiş ve bu soruları "Hiç Memnun Değilim(1), Pek Memnun Değilim(2), Vasat / Orta(3), Memnunum(4), Çok Memnunum(5)" seçeneklerinden birini seçerek cevaplandırmaları istenmiştir. Ayrıca katılımcıların demografik özellikleri Denizli Serbest Muhasebeci Mali Müşavirler Odası veri tabanından elde edilmiştir.

Anket kapsamında toplanan veriler, SPSS paket programından yararlanılarak analiz edilmiştir. Öncelikle ilgili anketlerde yer alan bilgiler programa kodlanarak bir veri tabanı oluşturulmuş. $\mathrm{Bu}$ veri tabanı yardımıyla anketin güvenilirliği, ankette yer alan soruların frekans dağılımları ve yüzdeleri hesaplanmış, eğitimden duyulan memnuniyetin belirli alt gruplar açısından farklılık gösterip göstermediği t-testi ve varyans analizi yardımıyla araştırılmıştır.

\subsection{Araştırmanın Evreni ve Örneklem}

T.C. Adalet Bakanlığı Bilirkişilik Daire Başkanlığı'nın Denizli ilinde bilirkişilik temel eğitim izni verdiği eğitim kuruluşları: Pamukkale Üniversitesi, Denizli SMMM Odası, Denizli Barosu ve çeşitli mühendis odalarıdır.

Araştırmanın kapsamını Denizli ilinde 1. dönem bilirkişilik eğitimlerine katılan muhasebe meslek mensupları oluşturmaktadır. Bu eğitime Denizli genelinde 102 meslek mensubu katılmış, bunun 101 tanesi eğitimi Denizli Serbest Muhasebeci Mali Müşavirler Odası'ndan almıştır. İlgili yasa gereği bilirkişilik eğitimlerinin geçerlilik süresi üç y1l olduğundan bu meslek mensupları 2018, 2019 ve 2020 yıllarında bilirkişilik faaliyetinde bulunabileceklerdir.

Bilirkişilik temel eğitimini almayan meslek mensuplarının ilgili dönemde bilirkişilik yapamayacağı düşünülürse, çalışmanın evrenini oluşturan 2018 yılında Denizli ilinde bilirkişilik yapabilecek olan 102 SMMM'nin 101 tanesi ankete katılım göstermiştir.

\subsection{Araştırmanın Güvenilirliği}

Güvenilirlik; bir testin ölçmek istenen şeyi tutarlı ve istikrarlı bir şekilde ölçme derecesidir. Soru grupları için en yaygın kullanılan içsel güvenilirlik indeksi Cronbach Alpha'dır. Bu indeks değişkenler arasındaki ortalama korelasyonu temel alarak, bir ölçekteki değişkenlerin iç tutarlılığını ölçer. Cronbach Alpha değeri 0.70 'in üzerinde olan ölçeklerin içsel tutarlılığa sahip olduğu, yani ele alınan ölçeğin güvenilir olduğu söylenir (Bayram, 2017: 194).

Araştırmanın güvenilirliğine yönelik yapılan analizde Cronbach Alpha değeri 0.951 olarak hesaplanmıştır. Bu sonuçtan hareketle anketin güvenilirliğinin yüksek olduğu söylenebilir. 


\subsection{Bulgular}

Yapılan analizlerde bilirkişi eğitimi alan meslek mensuplarının, cinsiyet, yaş, mesleki deneyim ve çalışma şekli gibi demografik özelliklerine ilişkin bulgular aşağıdaki tabloda gösterilmiştir.

Tablo 1. Demografik Bulgular (n=101)

\begin{tabular}{llll}
\hline & & Frekans & Yüzde(\%) \\
\hline \multirow{3}{*}{ Cinsiyet } & Kadın & 76 & 75.2 \\
& Erkek & 25 & 24.8 \\
\cline { 2 - 4 } & Toplam & 101 & 100 \\
\hline \multirow{3}{*}{ Yaş } & $30-40$ arası & 31 & 30.7 \\
& $41-50$ arası & 47 & 46.5 \\
& 50 üzeri & 23 & 22.8 \\
\cline { 2 - 4 } Çalışma Şekli & Toplam & 101 & 100 \\
& Bağımlı & 15 & 14.9 \\
& Bağımsız & 88 & 85.1 \\
\cline { 2 - 4 } Mesleki Deneyim & Toplam & 101 & 100 \\
& $5-10$ arası & 34 & 33.7 \\
& $11-20$ arası & 46 & 45.5 \\
& 20 üzeri & 21 & 20.8 \\
\cline { 2 - 4 } & Toplam & 101 & 100 \\
\hline
\end{tabular}

Ankete katılan meslek mensuplarının \%75.2'si erkek; \%24.8'i ise kadındır. Katılımcıların yaş ortalaması 45 olmakla birlikte yaklaşık yarısı 41 ile 50 yaş aralığındadır. Ayrıca bilirkişilik eğitimi alan en genç meslek mensubu 32 yaşında en yaşlısı ise 69 yaşındadır. Katılımcılar çalışma şekli açısından incelendiğinde, büyük bir kısmının (\%85.1) mesleki faaliyetini bağımsız yürüttüğü görülmektedir. 6754 sayılı Bilirkişilik Kanunu'nun 10. maddesinde bilirkişilik yapılacak uzmanlık alanında en az beş yıl fiilen çalışma şartı aranması nedeniyle eğitim katılımcıları arasında beş yıldan daha az tecrübeye sahip meslek mensubunun bulunmadığı görülmektedir. Mesleki deneyim açısından katılımcıların çoğunluğu 11 - 20 yıl arası deneyime sahipken, 20 yıl üzeri deneyime sahip meslek mensuplarının oranı \% 20.8'dir. Eğitim katılımcılarından en deneyimlisi 27 yıldır mali müşavirlik mesleğini yürütmektedir.

Bilirkişilik temel eğitiminin değerlendirilmesine yönelik olarak meslek mensuplarına yöneltilen sorulara verilen puanların standart sapma ve aritmetik ortalama değerleri Tablo 2'de gösterilmiştir.

Tablo 2. Meslek Mensuplarının Sorulara Verdikleri Puanların Aritmetik Ortalamaları

\begin{tabular}{lll}
\hline Sorular & Ortalama & $\begin{array}{l}\text { Standart } \\
\text { Sapma }\end{array}$ \\
\hline 1. Bu eğitim için ayrılan süreden memnun musunuz? & 4.56 & 0.607 \\
\hline 2. Eğitimin başlangıç ve bitiş saatlerinden memnun musunuz? & 4.63 & 0.612 \\
\hline $\begin{array}{l}\text { 3. Eğitimin planlanan saatlerde başlaması ve bitmesinden memnun } \\
\text { musunuz? }\end{array}$ & 4.64 & 0.610 \\
\hline $\begin{array}{l}\text { 4. Eğitimin Süresinin Eğitmen Tarafindan Etkin Kullanılmasından } \\
\text { memnun musunuz? }\end{array}$ & 4.72 & 0.472 \\
\hline
\end{tabular}




\begin{tabular}{lll}
\hline 5. Eğitimin yapıldığı mekandan memnun musunuz? & 4.76 & 0.472 \\
\hline 6. Eğiticilerin konuya hakimiyetinden memnun musunuz? & 4.82 & 0.385 \\
\hline 7. Konunun ele alınış şeklinden memnun musunuz? & 4.75 & 0.434 \\
\hline 8. Genel olarak eğiticilerin performansından memnun musunuz? & 4.80 & 0.400 \\
\hline 9. Genel olarak eğitim içeriğinden memnun musunuz? & 4.67 & 0.585 \\
\hline 10. Eğitimde kullanılan görsel malzemelerden memnun musunuz? & 4.73 & 0,508 \\
\hline 11. Eğitimin iş yaşamınıza katkısından memnun musunuz? & 4.53 & 0.593 \\
\hline $\begin{array}{l}\text { 12. Eğitim konularının uygulama ve örnek olaylarla } \\
\quad \text { desteklenmesinden memnun musunuz? }\end{array}$ & 4.63 & 0.543 \\
\hline 13. Eğitimin entelektüel seviyenize katkısından memnun musunuz? & 4.52 & 0.626 \\
\hline 14. Eğitimin kişisel gelişiminize katkısından memnun musunuz? & 4.56 & 0.573 \\
\hline $\begin{array}{l}\text { 15. Eğitimin bilgi ihtiyacınıza cevap verme düzeyinden memnun } \\
\text { musunuz? }\end{array}$ & 4.51 & 0.657 \\
\hline 16. Eğitimle ilgili genel memnuniyet düzeyiniz nedir? & 4.65 & 0.478 \\
\hline
\end{tabular}

Anket sorularına verilen cevapların ortalamalarının 4'ün üzerinde olması meslek mensuplarının bilirkişilik temel eğitimine ilişkin memnuniyet düzeylerinin oldukça yüksek olduğunu göstermektedir. Sırasıyla 4.82 ve 4.80 ortalamayla eğiticilerin konuya hakimiyeti ve performansları, eğitimin en fazla memnun kalınan tarafı olmuştur. Bu durum eğitimi veren ilgili kurumun eğitici seçimi noktasında özenli çalıştığının bir göstergesi olabilir.

Genel olarak yüksek bir memnuniyet seviyesinde olsa da katılımcıların; eğitimin bilgi ihtiyacına cevap verme düzeyinden, entelektüel seviyeye ve iş yaşamına katkısından ve eğitim için ayrılan süreden diğer durumlara kıyasla daha az memnun oldukları söylenebilir.

Araştırma kapsamında ayrıca, meslek mensuplarının bilirkişilik temel eğitimi hakkındaki görüşlerinin; cinsiyet, yaş, çalışma şekli ve mesleki deneyime göre farklılık gösterip göstermediği "t-testi” ve "One Way Anova" analizleri yardımıyla incelenmiştir.

Araştırma sonucunda, Tablo 3'de cinsiyete göre farklılık gösteren meslek mensubu görüşlerinin t-testi sonuçları görülmektedir. T-testi sonuçları gruplar arası varyansın eşit olup olmamasına göre farklılık göstereceğinden, öncelikle grupların varyanslarının eşitliği Levene testi ile belirlenmiştir. Bu doğrultuda varyansın durumuna göre t-testi sonucuna ulaşılmıştır. Tabloda yer almayan diğer görüşler, 0.05 anlamlılık düzeyinde, cinsiyete göre istatistiksel olarak anlamlı bir farklılık göstermemektedir.

Tablo 3. Cinsiyete Göre Farklılık Gösteren Görüşlerin T-Testi Sonuçları

\begin{tabular}{|c|c|c|c|c|c|}
\hline & & \multirow[b]{2}{*}{$\begin{array}{l}\text { Levene } \\
\text { Testi }\left(\mathrm{P}^{*}\right)\end{array}$} & \multicolumn{3}{|l|}{ t-test } \\
\hline & & & $\mathrm{t}$ & $\mathrm{df}$ & $\mathrm{P}^{*}$ \\
\hline \multirow{2}{*}{$\begin{array}{l}\text { 1. Bu eğitim için ayrılan } \\
\text { süreden memnun musunuz? }\end{array}$} & Varyanslar eşit & 0.173 & 3.22 & 99 & 0.002 \\
\hline & Varyanslar eşit değil & & 2.48 & 29.28 & 0.020 \\
\hline 2. Eğitimin başlangıç ve bitiş & Varyanslar eşit & 0.004 & 3.97 & 99 & 0.000 \\
\hline
\end{tabular}




\begin{tabular}{|c|c|c|c|c|c|}
\hline $\begin{array}{l}\text { saatlerinden memnun } \\
\text { musunuz? }\end{array}$ & \multicolumn{2}{|c|}{ Varyanslar eşit değil } & \multirow{2}{*}{$\begin{array}{l}2.86 \\
3.19\end{array}$} & \multirow{2}{*}{$\begin{array}{l}27.83 \\
99\end{array}$} & \multirow{2}{*}{$\begin{array}{l}0.008 \\
0.002\end{array}$} \\
\hline $\begin{array}{l}\text { 3. Eğitimin planlanan saatlerde } \\
\text { baslaması ve bitmesinden }\end{array}$ & Varyanslar eşit & 0.001 & & & \\
\hline memnun musunuz? & Varyanslar eşit d & & 2.30 & 27.79 & 0.029 \\
\hline \multirow{2}{*}{$\begin{array}{l}\text { 11. Eğitimin iş yaşamınıza } \\
\text { katkısından memnun musunuz? }\end{array}$} & Varyanslar eşit & 0.631 & 2.12 & 99 & 0.036 \\
\hline & Varyanslar eşit d & & 2.18 & 43.16 & 0.034 \\
\hline \multirow{2}{*}{$\begin{array}{l}\text { 12. Eğitim konularının } \\
\text { uygulama ve örnek olaylarla } \\
\text { desteklenmesinden memnun } \\
\text { musunuz? }\end{array}$} & Varyanslar eşit & 0.092 & 2.09 & 99 & 0.039 \\
\hline & Varyanslar eşit c & & 1.96 & 37.21 & 0.057 \\
\hline \multirow{2}{*}{$\begin{array}{l}\text { 14. Eğitimin kişisel } \\
\text { gelişiminize katkısından } \\
\text { memnun musunuz? }\end{array}$} & Varyanslar eşit & 0.955 & 2.52 & 99 & 0.013 \\
\hline & Varyanslar eşit d & & 2.52 & 41.08 & 0.015 \\
\hline
\end{tabular}

Kadın ve erkeklerin ilgili sorulara verdikleri cevapların ortalama değerleri dikkate alındığında, özellikle eğitimin süresi, başlangıç bitiş saatleri ve zamanlama olmakla birlikte, eğitim konularının örnek olaylarla desteklenmesinden, eğitimin iş hayatına ve kişisel gelişime katkısından duyulan memnuniyet erkek meslek mensuplarında anlamlı derecede daha fazladir.

Bilirkişilik eğitimi hakkında, bağımlı ya da bağımsız çalışılmasına göre anlamlı farklılık gösteren meslek mensubu görüşleri ise aşağıdaki tabloda verilmiştir.

Tablo 4. Çalıșma Șekline Göre Farklıık Gösteren Görüşlerin T-Testi Sonuçları

\begin{tabular}{|c|c|c|c|c|c|}
\hline & & \multirow[b]{2}{*}{$\begin{array}{l}\text { Levene } \\
\text { Testi }\left(\mathrm{P}^{*}\right)\end{array}$} & \multicolumn{3}{|l|}{ t-test } \\
\hline & & & $\mathrm{t}$ & df & $\mathrm{P}^{*}$ \\
\hline \multirow{2}{*}{$\begin{array}{l}\text { 5. Eğitimin yapıldı̆̆ } 1 \\
\text { mekandan memnun } \\
\text { musunuz? }\end{array}$} & Varyanslar eşit & 0.000 & 1.53 & 99 & 0.129 \\
\hline & Varyanslar eşit değil & & 2.35 & 35.33 & 0.024 \\
\hline \multirow{2}{*}{$\begin{array}{l}\text { 14. Eğitimin kişisel } \\
\text { gelişiminize katkısından } \\
\text { memnun musunuz? }\end{array}$} & Varyanslar eşit & 0.001 & 1.74 & 99 & 0.084 \\
\hline & Varyanslar eşit değil & & 2.22 & 25.09 & 0.035 \\
\hline
\end{tabular}

Bağımlı ve bağımsız çalışan katılımcıların eğitim hakkındaki sorulara verdikleri cevapların ortalama değerleri incelendiğinde, bağımlı çalışan meslek mensuplarının eğitimin yapıldığı mekandan ve eğitimin kişisel gelişimlerine katkısından bağımsız çalışanlara göre daha fazla memnun oldukları görülmüştür. Tablo 4'de yer almayan sorular açısından, katılımcıların çalışma şekli, memnuniyet seviyesinde istatistiksel olarak anlamlı bir farklılık yaratmamıştır.

Bilirkişilik eğitime katılan meslek mensuplarının, eğitim hakkındaki görüşlerinin yaş ve mesleki deneyim faktörleri açısından farklılık gösterip göstermediğinin belirlenmesi için ise "One Way Anova" testleri yapılmıştır. Meslek mensubunun yaşı ile memnuniyet düzeyi arasındaki farklılığın istatistiksel olarak anlamlı olduğu sorulara ilişkin sonuçlar Tablo 5'de gösterilmiştir. Buna göre, sadece eğitimin entelektüel seviyeye katkısından duyulan 
memnuniyette, katılımcıların yaşlarına göre anlamlı farklılık gözlenmiştir. Eğitim hakkındaki diğer görüşler, farklı yaş grupları arasında anlamlı farklılıklar göstermemektedir.

Tablo 5. Yaşa Göre Farklılık Gösteren Görüşlerin Anova Testi Sonuçları

\begin{tabular}{|c|c|c|c|c|c|c|c|}
\hline & & $\begin{array}{l}\text { Kareler } \\
\text { Toplamı }\end{array}$ & $\mathrm{df}$ & $\begin{array}{l}\text { Ortalama } \\
\text { Kare }\end{array}$ & $\mathrm{F}$ & $\mathrm{P}^{*}$ & $\begin{array}{l}\text { Levene } \\
\text { Testi }\left(\mathrm{P}^{*}\right)\end{array}$ \\
\hline \multirow{3}{*}{$\begin{array}{l}\text { 13.Eğitimin } \\
\text { entelektüel } \\
\text { seviyenize } \\
\text { katkısindan } \\
\text { memnun } \\
\text { musunuz? }\end{array}$} & Gruplar Aras1 & 2.434 & 2 & 1.217 & \multirow[t]{3}{*}{3.244} & \multirow[t]{3}{*}{0.043} & \multirow[t]{3}{*}{0.002} \\
\hline & Grup içi & 36.756 & 98 & 0.375 & & & \\
\hline & Toplam & 39.188 & 100 & & & & \\
\hline
\end{tabular}

13. soru ile ilgili olarak meslek mensubu yaş aralıkları arasında oluşan farklılığın hangi yaş aralıklarında olduğunu belirleyebilmek için Post Hoc çoklu karşılaştırma testlerinin yapılması gerekmektedir. Bu noktada grupların varyansının eşit olması ve eşit olmaması durumlarında kullanılan test istatistikleri farklılık gösterecektir. Çalışmadaki Anova testlerinde varyansların eşit olduğu durumda, grupların örneklem sayıları birbirine eşit olmadığından Scheffe Testi; varyansların eşit olmadığı durumda ise Tamhane's T2 testi uygulanmıştır.

Öncelikle varyanslarının eşitliğini belirleyebilmek için Levene testi sonuçlarına bakmak gerekir. Tablo 5'deki Levene P değeri grupların varyansının eşit olmadığını göstermektedir. $\mathrm{Bu}$ doğrultuda yapılan çoklu karşılaştırma testlerinden Tamhane's T2 testi analiz sonuçları aşağıdaki tabloda yer almaktadır.

Tablo 6. 13. Soruda Yaş Grupları Arasında Oluşan Farklılığın Kaynağına İliş̧in Uygulanan Tamhane's T2 Testi Sonuçları

\begin{tabular}{|c|c|c|c|c|c|}
\hline & $\begin{array}{l}\text { Yaş Aralığ } 1 \\
\text { (I) }\end{array}$ & Yaş Aralığ $1(\mathrm{~J})$ & $\begin{array}{l}\text { Ortalama } \\
\text { Fark1 (I-J) }\end{array}$ & $\begin{array}{l}\text { Standart } \\
\text { Hata }\end{array}$ & $\mathrm{P}^{*}$ \\
\hline \multirow{6}{*}{$\begin{array}{l}\text { 13.Eğitimin } \\
\text { entelektüel } \\
\text { seviyenize } \\
\text { katkısından } \\
\text { memnun } \\
\text { musunuz? }\end{array}$} & \multirow[t]{2}{*}{$30-40$} & $41-50$ & -0.156 & 0.160 & 0.706 \\
\hline & & 50 üzeri & -0.428 & 0.162 & 0.032 \\
\hline & \multirow[t]{2}{*}{$41-50$} & $30-40$ & 0.156 & 0.160 & 0.706 \\
\hline & & 50 üzeri & -0.272 & 0.123 & 0.088 \\
\hline & \multirow[t]{2}{*}{50 üzeri } & $30-40$ & 0.428 & 0.162 & 0.032 \\
\hline & & $41-50$ & 0.272 & 0.123 & 0.088 \\
\hline
\end{tabular}

Tablo 6'da görüldüğü üzere bilirkişilik eğitimine katılan meslek mensuplarının 13. soruya ilişkin görüşlerinin, 30 - 40 yaş arası ile 50 yaş üzeri meslek mensupları arasında anlamlı farklılık gösterdiği görülmektedir. Farklı yaş gruplarındaki katılımcıların eğitim hakkındaki sorulara verdikleri cevapların ortalama değerleri incelendiğinde, 50 yaş üzeri meslek mensuplarının, eğitimin entelektüel seviyeye katkısından, 30 - 40 yaş arası katılımcılara göre anlamlı ölçüde daha fazla memnun oldukları görülmüştür. 
Katılımcıların mesleki deneyimi ile eğitim hakkındaki görüşlerinin arasındaki farklılığın istatistiksel olarak anlamlı olduğu sorulara ilişkin Anova testi sonuçları ise Tablo 7'de yer almaktadir.

Tablo 7. Mesleki Deneyime Göre Farklılık Gösteren Görüsşlerin Anova Testi Sonuçları

\begin{tabular}{|c|c|c|c|c|c|c|c|}
\hline & & $\begin{array}{l}\text { Kareler } \\
\text { Toplamı }\end{array}$ & df & $\begin{array}{l}\text { Ortalama } \\
\text { Kare }\end{array}$ & $\mathrm{F}$ & $\mathrm{P}^{*}$ & $\begin{array}{l}\text { Levene } \\
\text { Testi }\left(\mathrm{P}^{*}\right)\end{array}$ \\
\hline \multirow{3}{*}{$\begin{array}{l}\text { 1.Bu eğitim için } \\
\text { ayrılan süreden } \\
\text { memnun } \\
\text { musunuz? }\end{array}$} & Gruplar Aras1 & 2.292 & 2 & 1.146 & \multirow[t]{3}{*}{3.251} & \multirow[t]{3}{*}{0.043} & \multirow[t]{3}{*}{0.172} \\
\hline & Grup içi & 34.540 & 98 & 0.352 & & & \\
\hline & Toplam & 36.832 & 100 & & & & \\
\hline \multirow{3}{*}{$\begin{array}{l}\text { 13.Eğitimin } \\
\text { entelektüel } \\
\text { seviyenize } \\
\text { katkısından } \\
\text { memnun } \\
\text { musunuz? }\end{array}$} & Gruplar Aras1 & 3.567 & 2 & 1.784 & \multirow[t]{3}{*}{4.907} & \multirow[t]{3}{*}{0.009} & \multirow[t]{3}{*}{0.329} \\
\hline & Grup içi & 35.621 & 98 & 0.363 & & & \\
\hline & Toplam & 39.188 & 100 & & & & \\
\hline \multirow{3}{*}{$\begin{array}{l}\text { 16.Eğitimle } \\
\text { ilgili genel } \\
\text { memnuniyet } \\
\text { düzeyiniz nedir? }\end{array}$} & Gruplar Aras1 & 2.377 & 2 & 1.189 & \multirow[t]{3}{*}{5.684} & \multirow[t]{3}{*}{0.005} & \multirow[t]{3}{*}{0.002} \\
\hline & Grup içi & 20.494 & 98 & 0.209 & & & \\
\hline & Toplam & 22.871 & 100 & & & & \\
\hline
\end{tabular}

$* \mathrm{p}<0.05$

Tablo 7'ye göre; eğitimin süresinden ve eğitimin entelektüel seviyeye katkısından duyulan memnuniyet ile eğitimle ilgili genel memnuniyet, farklı mesleki deneyim sürelerine sahip katılımcılar arasında anlamlı farklılıklar göstermektedir.

1., 13. ve 16. sorularla ilgili olarak, katılımcıların mesleki deneyim süreleri arasında oluşan farklılığın, hangi deneyim seviyelerinde olduğunu belirleyebilmek için Post Hoc çoklu karşılaştırma testleri yapılmıştır.

Varyansların eşitliğini belirleyebilmek için yapılan ve Tablo 7'de gösterilen Levene testi sonuçlarına göre; soru 1 ve soru 13 için grupların varyansları eşittir ve Scheffe Testi uygulanmıştır. Soru 16 için ise grupların varyansının eşit olmamasından dolayı Tamhane's T2 testi uygulanmıştır. Tablo 8 ve Tablo 9'da, Scheffe ve Tamhane's T2 testlerinin analiz sonuçları sırasıyla verilmiştir.

Tablo 8. 1. ve 13. Sorularda Mesleki Deneyim Seviyeleri Arasındaki Farkııı̆ı̆ Kaynağına İlişsin Uygulanan Scheffe Testi Sonuçları

\begin{tabular}{|c|c|c|c|c|c|}
\hline & $\begin{array}{l}\text { Mesleki Deneyim } \\
\text { Aralığ } 1 \text { (I) }\end{array}$ & $\begin{array}{l}\text { Mesleki Deneyim } \\
\text { Aralığ } 1(\mathrm{~J})\end{array}$ & $\begin{array}{l}\text { Ortalama } \\
\text { Fark1 (I-J) }\end{array}$ & $\begin{array}{l}\text { Standart } \\
\text { Hata }\end{array}$ & $\mathrm{P}^{*}$ \\
\hline \multirow{5}{*}{$\begin{array}{l}\text { 1.Bu eğitim için } \\
\text { ayrilan süreden } \\
\text { memnun } \\
\text { musunuz? }\end{array}$} & \multirow[t]{2}{*}{$5-10$} & $11-20$ & -0.321 & 0.134 & 0.049 \\
\hline & & 20 üzeri & -0.314 & 0.165 & 0.143 \\
\hline & \multirow[t]{2}{*}{$11-20$} & $5-10$ & 0.321 & 0.134 & 0.049 \\
\hline & & 20 üzeri & 0.007 & 0.156 & 0.999 \\
\hline & 20 üzeri & $5-10$ & 0.314 & 0.165 & 0.143 \\
\hline
\end{tabular}


UTKU \& KURTCEBE

\begin{tabular}{llllll} 
& & $11-20$ & -0.007 & 0.156 & 0.999 \\
\hline & $5-10$ & $11-20$ & -0.366 & 0.136 & 0.031 \\
\cline { 2 - 6 } $\begin{array}{l}\text { 13.Eğitimin } \\
\text { entelektüel }\end{array}$ & & 20 üzeri & -0.450 & 0.167 & 0.031 \\
\cline { 2 - 6 } $\begin{array}{l}\text { seviyenize } \\
\text { katkısindan } \\
\text { memnun } \\
\text { musunuz? }\end{array}$ & $11-20$ & $5-10$ & 0.366 & 0.136 & 0.031 \\
\cline { 2 - 6 } & & 20 üzeri & -0.084 & 0.159 & 0.870 \\
\hline
\end{tabular}

$* \mathrm{p}<0.05$

Tablo 9. 16. Soruda Mesleki Deneyim Seviyeleri Arasındaki Farklılığın Kaynağına İlişsin Uygulanan Tamhane's T2 Testi Sonuçları

\begin{tabular}{|c|c|c|c|c|c|}
\hline & $\begin{array}{l}\text { Mesleki Deneyim } \\
\text { Aralığı (I) }\end{array}$ & $\begin{array}{l}\text { Mesleki Deneyim } \\
\text { Aralığı }(\mathrm{J})\end{array}$ & $\begin{array}{l}\text { Ortalama } \\
\text { Fark1 (I-J) }\end{array}$ & $\begin{array}{l}\text { Standart } \\
\text { Hata }\end{array}$ & $\mathrm{P}^{*}$ \\
\hline \multirow{6}{*}{$\begin{array}{l}\text { 16.Eğitimle } \\
\text { ilgili genel } \\
\text { memnuniyet } \\
\text { düzeyiniz } \\
\text { nedir? }\end{array}$} & \multirow[t]{2}{*}{$5-10$} & $11-20$ & -0.341 & 0.106 & 0.006 \\
\hline & & 20 üzeri & -0.273 & 0.133 & 0.131 \\
\hline & \multirow[t]{2}{*}{$11-20$} & $5-10$ & 0.341 & 0.106 & 0.006 \\
\hline & & 20 üzeri & 0.068 & 0.118 & 0.919 \\
\hline & \multirow[t]{2}{*}{20 üzeri } & $5-10$ & 0.273 & 0.133 & 0.131 \\
\hline & & $11-20$ & -0.068 & 0.118 & 0.919 \\
\hline
\end{tabular}

$* \mathrm{p}<0.05$

Tablo 8'de görüldüğü üzere, bilirkişilik eğitimine katılan meslek mensuplarının eğitim için ayrılan süreden duyduğu memnuniyet, 5 - 10 yıllık mesleki deneyimi olan katılımcılar ile 11 20 yıllık mesleki deneyimi olan katılımcılar arasında anlamlı düzeyde farklılık göstermektedir. Farklı mesleki kıdeme sahip katılımcıların eğitim hakkındaki sorulara verdikleri cevapların ortalama değerleri incelendiğinde, deneyimli meslek mensuplarının eğitim için ayrılan süreden daha fazla memnun oldukları görülmüştür. Bunun yanında eğitimin entelektüel seviyeye katkısından duyulan memnuniyet, hem 5 - 10 yıllık ile 11 - 20 yıllık deneyime sahip meslek mensupları arasında, hem de 5 - 10 yıllık ile 20 yıl üzeri deneyime sahip meslek mensupları arasında anlamlı düzeyde farklılık göstermektedir. Meslekte nispeten yeni olan meslek mensupları diğer katılımcılara göre, eğitimin entelektüel seviyelerine anlamlı ölçüde daha az katkı yaptığını düşünmektedirler.

Son olarak Tablo 9'dan hareketle, muhasebe meslek mensuplarının bilirkişilik eğitimi hakkındaki genel memnuniyet seviyesi, 5 - 10 yillık mesleki deneyimi olanlar ile 11 - 20 yıllık mesleki deneyimi olanlar arasında anlamlı düzeyde farklılık göstermektedir. Bu soruya verilen cevapların ortalama değerleri incelendiğinde eğitimden en fazla memnun görünen katılımcılar, 5 üzerinden 4.78 ortalamayla 11 - 20 yıl deneyime sahip meslek mensuplarıdır.

\section{SONUÇ VE DEĞERLENDİRME}

Çağdaş hukuk sistemlerinde sıklıkla başvurulan ve demokrasinin vazgeçilmezi yargı için önemli bir ispat aracı olan bilirkişilik müessesesi, adalet sisteminin sağlıklı işleyebilmesi ve yargılama faaliyetlerinin hızlı ve sorunsuz ilerlemesi için sağlam temellere dayandırılmalıdır. Türkiye'de, 24.11.2016 tarihinde yürürlüğe giren 6754 sayılı Bilirkişilik Kanunu, çok eski bir 
geçmişi olan bilirkişilik müessesesinin kurumsallaşması yönünde atılmış önemli bir adımdır. Yasa ile getirilen düzenlemeler çerçevesinde, bilirkişiler sertifikalı ve akredite kişiler olmuş ve bilirkişilik geçmiş uygulamaların aksine daha profesyonel bir zemine oturtulmuştur.

Kanun çerçevesinde atılan önemli adımlardan biriside bilirkişilik temel eğitimidir. Kanun, bilirkişi listesine kayıt olabilmek için teorik ve uygulama eğitimini zorunlu tutmuştur. İlgili yönetmelik ve genelgelerde uygulama usul ve esasları ayrıntısıyla belirlenen temel eğitim, nitelikli bilirkişilerin adalete hizmet etmesini amaçlamaktadır. Bilirkişilik temel eğitimiyle katılımcılara, teorik eğitimin yanında UYAP Bilirkişi Sistemi hakkında da eğitimler verilmekte ve böylelikle yargılama süreçlerinde yaşanan zaman ve mekan kaynaklı sorunların önüne geçmek hedeflenmiştir.

Davalara konu olan olayların birçoğunun ekonomik ve mali bir tarafının olması sebebiyle, yargının uzmanlığına başvurduğu kişilerin başında mali müşavirler gelmektedir. $\mathrm{Bu}$ çerçevede çalışma kapsamında, bilirkişilik temel eğitimlerinin değerlendirilmesi için TÜRMOB organizasyonunda Denizli ilinde, Denizli SMMM Odası tarafindan gerçekleştirilen Bilirkişilik Temel Eğitimine katılan meslek mensuplarının görüşleri analiz edilmiştir. Bu analizde, gerek eğitimin süresi, gerekse eğiticiler, eğitimin içeriği ve eğitimin verildiği mekan açısından memnuniyet düzeyleri ortaya konmuştur. Araştırma sonucu göstermektedir ki; bilirkişilik eğitimlerine katılan meslek mensuplarının aldıkları eğitimden memnuniyet düzeyleri oldukça yüksektir. Eğiticilerin konuya hakimiyeti ve performansları, eğitimin en fazla memnun kalınan tarafi olmuştur. Bu durum eğitimi veren ilgili kurumun eğitici seçimi noktasında özenli çalıştığının bir göstergesidir. Eğiticilerden yüksek seviyede memnun olan meslek mensuplarının, bilgi ihtiyacına cevap verme düzeyi ve eğitime ayrılan sürede, memnuniyet seviyelerinin düşmesi nedeniyle kanun kapsamındaki asgari eğitim süreleri yeniden gözden geçirilebilir. Meslekte nispeten yeni olan meslek mensupları eğitimin süresinin yeterli olmadığg görüşündedir. Özellikle, altı saatlik pratik eğitim bölümü, gerek uzmanlık alanlarına göre örnek raporlama noktasında, gerekse süre yönünden yeniden gözden geçirilmelidir. Eğitim kurumları, bu beklentiye cevap verme noktasında eğitim programlarını zenginleştirebilirler. Eğitimin süresi, başlangıç bitiş saatleri ve zamanlaması gibi konularda kadın katılımcıların memnuniyet dereceleri anlamlı derecede daha düşüktür. Bu noktada, eğitim planlaması yapılırken, eğitime katılım sağlayan meslek mensuplarının süregelen iş yükü ve mali takvimin de dikkate alınması gerekmektedir.

Bilirkişilik mevzuatı ile ortaya konan temel eğitim hedefini karşılamak ve bilirkişilik müessesinin uluslararası standartlarda işleyişini sağlamak amacıyla yetkili kurumlarca yapılan eğitimlerin ihtiyaca uygun şekilde geliştirilmesi büyük önem arz etmektedir.

Sonuç olarak, her ne kadar muhasebe meslek mensupları alanlarında uzmanlıklarını meslek ruhsatlarıyla belgelemiş olsalar da, bilirkişilik kanunu ile getirilen eğitim şartı, kendi içerisinde ayrı bir işleyişi olan bilirkişilik uygulamaları hakkında meslek mensubuna bilirkişilik faaliyetlerinde önemli katkılar sağlayacaktır. Aynı zamanda hukuki ve mali mevzuat hakkındaki bilgilerini güncel tutma firsatı da verecektir. 


\section{KAYNAKÇA}

AKCAN, R. (2015). "Bilirkişilik Kanunu Tasarısı Taslağı Hakkında Bazı Tespitler”, İnönü Üniversitesi Hukuk Fakültesi Dergisi, 2(Özel Say1): 653-664.

ATALI, M. (2016). “6754 Sayılı Bilirkişilik Kanunu ve Hukuki Konularda Bilirkişilik”, Ankara Üniversitesi Hukuk Fakültesi Dergisi, 65(4): 3271-3282.

BAYRAM, N. (2017). Sosyal Bilimlerde SPSS İle Veri Analizi, Ezgi Kitabevi, 6. Baskı, Bursa.

BULUT, E. (2001). "Bilirkişi Seçimi Ve Bilirkişi Raporlarının Bağlayıcılığı”, Mevzuat Dergisi, 47(2001). https://www.mevzuatdergisi.com/2001/11a/02.htm (Erişim Tarihi: 08 Kasim2018).

ERDOĞAN, E. ve TORAMAN, B. (2017). Bilirkişilik Temel Eğitimi Kaynak Kitabı, Bilirkişilik Daire Başkanlığı Yayınları, Ankara.

GÜNEŞ, C. (2015). Bilirkişilik Mesleğinde Rapor Düzenleme Yöntemi ve Örnekleri, İSMMMO Yayınları, İstanbul.

İNAN, A. ve KUMKALE, R. (2010). Mali Müşavirler İçin Bilirkişilik Kılavuzu, Merkez Matbaacılık, 2. Baskı, Ankara.

KALAYCI, Ş. (2010). SPSS Uygulamalı Çok Değişkenli İstatistik Teknikleri, Asil Yayınc1lık, 5. Bask1, Ankara.

KISACIK, H. (2018). “Adli Muhasebe ve 6754 Sayılı Bilirkişilik Kanunu Kapsamında Muhasebe Bilirkişiliği”, Turkish Studies Academic Journal, 13/15: 291-303.

KÖK, A. N. (2017). “6754 Sayılı Bilirkişilik Kanunu Neler Getirdi?”, Uyuşmazlık Mahkemesi Dergisi, 10: 445-454.

SOYDAN, B. ve BIYAN, Ö. (2016). "Bilirkişilik Kurumsallaşıyor mu? Bilirkişilik Kanunu Kapsamında Bir Değerlendirme”, Vergi Sorunları Dergisi, 339: 126-145.

TÜRKAY, İ. (2017). “6754 Sayılı Bilirkişilik Kanununun Genel Değerlendirilmesi”, Mali Çözüm Dergisi, 139: 111-135.

T.C. YASALAR (13.06.1989). 3568 Sayılı Serbest Muhasebeci Mali Müşavirlik ve Yeminli Mali Müşavirlik Kanunu. Ankara: Resmi Gazete (20194 say1l1).

T.C. YASALAR (24.10.2016). 6754 Sayılı Bilirkişilik Kanunu. Ankara: Resmi Gazete (29898).

T.C. ADALET BAKANLIĞI (03.08.2017). Bilirkişilik Yönetmeliği. Ankara: Resmi Gazete (30143).

T.C. ADALET BAKANLIĞI (11.08.2017). Bilirkişilik Temel Eğitiminin Usul ve Esasları. Ankara: Genelge (169).

T.C. ADALET BAKANLIĞI, Bilirkişilik Daire Başkanlığı, http://bilirkisilik.adalet.gov.tr

TÜRMOB, Türkiye Serbest Muhasebeci Mali Müşavirler ve Yeminli Mali Müşavirler Odaları Birliği, https://www.turmob.org.tr 